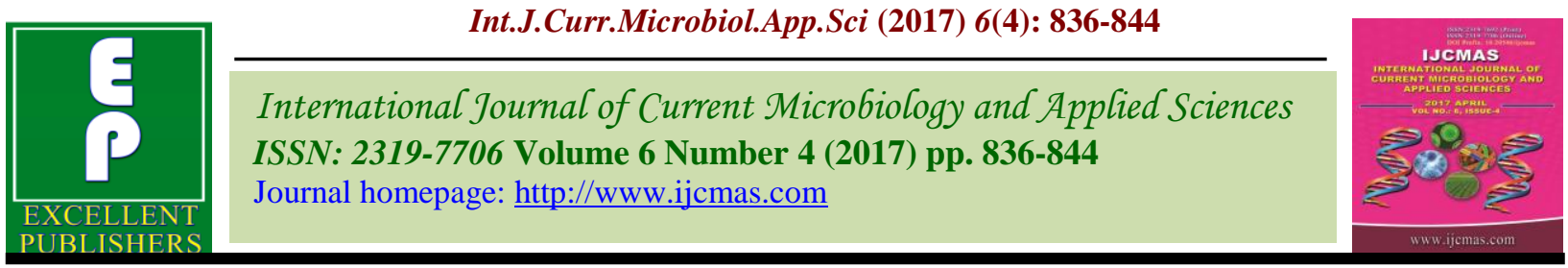

Original Research Article

https://doi.org/10.20546/ijcmas.2017.604.104

\title{
Chryseobacterium indologenes A Novel Root Nodule Endophyte in Vigna radiata
}

\author{
Archana Dhole*, Harsha Shelat and Deepak Panpatte \\ Anand Agricultural University, Anand, Gujarat, India-388110, India \\ *Corresponding author
}

A B S T R A C T

Keywords

Endophytic nonrhizobial bacteria, Chryseobacterium indologenes, Plant growth promoting bacteria, nifH gene,

Article Info

Accepted: 06 March 2017 Available Online: 10 April 2017
Endophytic non rhizobial bacterial stain AM2 was isolated from root nodules of Vigna radiate. The bacterium was Gram-negative, yellow pigmented, nonspore forming, motile and oxidase positive. Phylogeny of 16S rRNA gene sequences revealed that the strain belonged to the genus Chryseobacterium, a member of family Flavobacteriaceae. Closest phylogenetic relatives to it were Chryseobacterium indologenes strain LMG8337 and Chryseobacterium indologenes strain NBRC 14944, respectively was showing $97 \%$ and 95\% 16S rRNA gene sequence similarity. Strain showed presence of nif $\mathrm{H}$ gene of $\sim 380$ bp. It also exhibit nitrogen fixation ability around $19.55 \mathrm{mg} \mathrm{N} \mathrm{g}^{-1}$ of glucose consumed with indole acetic acid producing capability of $87.04 \mu \mathrm{g} \mathrm{ml}^{-1}$. However, phosphate solubilization and siderophore production was absent. 1-Aminocyclopropane-1carboxylate deaminase activity was also present. In present study, to the best of our knowledge and literature surveyed endophytic non rhizobial C. indologenes AM2 isolated first time from root nodules of mungbean possessing plant growth promoting attributes.

\section{Introduction}

Mungbean (Vigna radiata) is one of the important legumes and a well-known economic crop in tropical and subtropical countries. It is often included in rice or cornbased crop rotation to replenish nitrogen, improve soil fertility. Among pulses, mung bean has been assigned a higher order of nutritive merit next to gram and black gram. These crispy beans are one of the most vital pulses in various oriental food and delicacies. In Indian economy, it is hardly overemphasized due to its valuable and easily digestible protein $(24 \%)$, fat $(1.3 \%)$, calcium (124 mg), phosphorus (326 mg), iron (7.3 mg) and vitamin B. As a leguminous plant, mungbean could be nodulated by rhizobia, causing the formation of a new organ (i.e. nodule) and establishing a nitrogen-fixing symbiosis. Within the root nodules, these bacteria fix atmospheric nitrogen into ammonia, providing the nitrogen requirements of cultivated legumes and reducing the need for inorganic fertilizer which can be expensive and cause environmental problems (Pongsilp and Nuntagij, 2007).

Rhizobia are soil bacteria capable of eliciting nodules on leguminous plant roots and/or stems in which the bacteria fix nitrogen. In addition to species in the genera Allorhizobium, Azorhizobium, 
Bradyrhizobium, Mesorhizobium, Rhizobium and Ensifer (former Sinorhizobium species), symbiotic strains belonging to a wide range of bacterial genera have been reported recently from root nodules of several legume species, including Devosia neptuniae (Rivas et al., 2002), Methylobacterium nodulans (Sy et al., 2001), Ochrobactrum lupini and Ochrobactrum cytisi (Zurdo- Pineiro et al., 2007) in the Alphaproteobacteria, plus several species of Ralstonia and Burkholderia (Moulin et al., 2000; Vandamme et al., 2002) in the Betaproteobacteria (Zhang et al., 1996; Lin et al., 2008; Rajendran et al., 2008; Ibanez et al., 2009; Egamberdieva et al., 2010; Tariq et al., 2012; and Pandya et al., 2013).

In the last few decades, endophytic bacteria from root nodules have attracted more and more attention as novel resources for plant growth promotion and biological control of plant diseases. In earlier days, it was believed that the root nodules of leguminous plants accommodate only endophytic bacteria of genus Rhizobium, Mesorhizobium, Bradyrhizobium, Ensifer and Azorhizobium collectively called rhizobial; which can only fix atmospheric nitrogen symbiotically. But root nodules also accommodate various nonrhizobial bacteria having definite influence on the survival, nodulation and grain yield of the crop. In the absence of positive nodulation tests, they can be regarded as endophytic nonrhizobial bacteria.

In past decade, several symbionts capable of forming nodules and fixing nitrogen in legume roots have been documented and grouped under $\alpha, \beta$ and $\gamma$ Proteobacteria, which include Methylobacterium nodulans, Blastobacter denitrificans, Devosia sp., Ochrobactrum lupini, Agrobacterium, Phyllobacterium trifolii, Herbaspirillum lustianum Ralstonia taiwanensis, Burkholderia tuberum, Burkholderia phymatum and Burkholderia cepacia (Balachandar et al., 2007). These endophytic non-rhizobial bacteria have beneficial influence on the host plants, including plant growth promotion (Vessey, 2003; Kuklinsky et al., 2004; Ibanez et al., 2009; Tariq et al., 2012), nitrogen fixation (Andrews et al., 2010), siderophore mediated interactions (Rajendran et al., 2008; Andrews et al., 2010), promotion of plant stress tolerance (Andrews et al., 2010) and biological control of plant pathogens.

Nitrogen is one of the limiting nutrients; these bacteria provide it by biological nitrogen fixation with the help of nitrogenase enzyme. Multiple subunits of nitrogenase enzyme responsible for conversion of atmospheric nitrogen to ammonia are encoded by three genes nif $\mathrm{H}$, nif $\mathrm{D}$ and nifK (Rubio and Ludden, 2002). Of the three, nif $\mathrm{H}$ encoding the dinitrogenase reductase subunit is the most sequenced and studied. Multiple studies report about the beneficial effect of coinoculating rhizobia with other bacteria (Zhang et al., 1996; Rajendran et al., 2008; Egamberdieva et al., 2010).

All previously mentioned studies suggest that besides rhizobia, endophytic non rhizobial bacteria are present inside root nodules, which may have beneficial effects on the host plant.

Biodiversity of endophytic non rhizobial bacteria from leguminous plants were reported earlier. While most studies reported occurrence of these bacteria from soybean $(\mathrm{Li}$ et al., 2008; Zhang et al., 1996; Dalal and Kulkarni, 2013; Kuklinsky et al., 2004), groundnut (Ibanez et al., 2009); the vast plethora of mungbean and uncultivated wild legumes remain largely unexplored. In the present study, our aim was to isolate and identify endophytic non rhizobial bacteria associated with root nodules possessing nifH gene from Vigna radiata. 


\section{Materials and Methods}

\section{Isolation and screening}

Root nodule samples were collected from Anand farms of leguminous crop Vigna radiata (mung bean).

The excised root nodules were surface sterilized with $0.1 \% \quad \mathrm{HgCl}_{2}$. After surface sterilization, isolation of endophytic nonrhizobial bacteria was carried out as suggested by Selvakumar et al., (2008) on yeast extract mannitol agar and Nitrogen Free Bromo Thymol Blue agar.

For confirmation of surface sterilization, water from final rinse was spreaded on $\mathrm{R}_{2} \mathrm{~A}$ medium (Peptone- 0.5 g, Starch- $0.5 \mathrm{~g}$, Glucose- $0.5 \mathrm{~g}$, Yeast Extract- $0.5 \mathrm{~g}$, Casein Hydrolysate- $0.5 \mathrm{~g}$, Dipotassium phosphate$0.3 \mathrm{~g}$, Sodium pyruvate- $0.3 \mathrm{~g}$, Magnesium sulphate anhydrous- $0.024 \mathrm{~g}$, Agar- $15 \mathrm{~g}$, distilled water- $1000 \mathrm{ml}$ and $\mathrm{pH}-7.2)$ and incubated at $28 \pm 2^{\circ} \mathrm{C}$ for $36 \mathrm{~h}$. Isolated colonies further screened on Dworkin and Foster (DF) salt minimal nitrogen free medium and incubated at $28 \pm 2^{\circ} \mathrm{C}$ for $48 \mathrm{~h}$.

\section{Detection of $n i f \mathrm{H}$ gene}

Pure isolates selected after screening on nitrogen free medium; subjected to PCR amplification of region coding for Fe-protein (component II) of nitrogenase enzyme complex using degenerate primers (Pol F- 5' TGCGAYCCSAARGCBGACTC 3' and Pol R- 5' ATSGCCATCATYTCRCCGGA 3') by using colony PCR as described by Mirhendi et al., (2007) except PCR amplification conditions were modified as per requirement of $n i f \mathrm{H}$ gene amplification as follows; initial denaturation at $94^{\circ} \mathrm{C}$ for $5 \mathrm{~min}$; denaturation at $94^{\circ} \mathrm{C}$ for $30 \mathrm{sec}$; annealing at $55^{\circ} \mathrm{C}$ for 30 sec; extension at $72^{\circ} \mathrm{C}$ for $30 \mathrm{sec}$ for 25 cycles and final extension at $72^{\circ} \mathrm{C}$ for $10 \mathrm{~min}$.

\section{Plant growth promoting traits}

\section{Quantitative estimation of nitrogen fixation}

Quantitative estimation of nitrogen was estimated by Micro-Kjeldahl method (AOAC 1965) and sugar utilization was estimated by Fehling's method.

\section{IAA production}

IAA production assay was performed as described by Glickmann and Dessaux (1995). Bacterial isolates were grown in glucose phosphate broth containing L-tryptophan $(0.005 \mathrm{M})$ for 3 days on shaker at $100 \mathrm{rpm}$ and then centrifuged at $3000 \mathrm{rpm}$ for $20 \mathrm{~min}$. One $\mathrm{ml}$ supernatant was mixed with $2 \mathrm{ml}$ of Salkowaski's reagent $\left(2.03 \mathrm{~g}\right.$ of $0.5 \mathrm{M} \mathrm{FeCl}_{3}+$

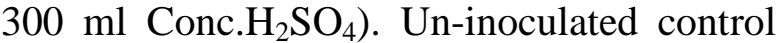
was kept for comparison. The intensity of pink color developed within 30 min was measured at $535 \mathrm{~nm}$ in UV/VIS spectrophotometer. The quantity of IAA was determined by comparison with an IAA standard curve and expressed in $\mu \mathrm{g} \mathrm{ml}^{-1}$.

\section{Phosphate solubilizing capacity}

Phosphate solubilization activity of selected isolates was determined by the method described by Taurian et al., (2010) on Sperber's agar. Bacterial isolates were inoculated by using a sterile toothpick on respective plates under an aseptic condition and were incubated at $28 \pm 2{ }^{\circ} \mathrm{C}$ for five days. Observations on colony diameter and solubilization of Tri-calcium phosphate was recorded at every $24 \mathrm{~h}$. Clear zone formation around the growing colony indicated the phosphate solubilization activity.

\section{Efficiency of siderophore production}

Production of siderophores was determined using chrome-azurol-S (CAS) agar method 
(Schwyn and Neilands, 1987). Bacterial isolates were inoculated at the center of a CAS agar plate. Siderophore production was assessed by change in the color of the medium surrounding colony from blue to orange after incubation at $28^{\circ} \pm 2{ }^{\circ} \mathrm{C}$ for 5 days.

$\mathrm{ACC}$

(1-Aminocyclo-propane-1Carboxylate) deaminase production

ACC deaminase enzyme production ability was checked based on their ability to use ACC as a sole nitrogen source in the minimal medium (Duan et al., 2009). Cultures were spot inoculated on plates containing minimal medium supplemented with $3 \mathrm{mM}$ ACC substrate. Plates containing minimal medium without ACC were served as negative control and with $\left(\mathrm{NH}_{4}\right)_{2} \mathrm{SO}_{4}\left(2.0 \mathrm{gm} \mathrm{l}^{-1}\right)$ as a nitrogen source served as positive control. The plates were incubated for 4 days at $28 \pm 2{ }^{\circ} \mathrm{C}$. Growth of isolates on ACC supplemented plates was compared with positive and negative control plates.

\section{Characterization and identification}

Morphological, cultural and biochemical characteristics of purified isolates were studied by standard procedures described by Holt et al., (1994). Selected isolate after screening for gene encoding for nitrogenase enzyme was grown in Luria broth for $24 \mathrm{~h}$ and genomic DNA was extracted by C-TAB method (Jhala et al., 2014). The integrity and concentration of purified DNA were determined by agarose gel electrophoresis. The total genomic DNA extracted was dissolved in Tris-EDTA buffer and stored at $4^{\circ} \mathrm{C}$. The sequencing of the $16 \mathrm{~S}$ ribosomal RNA (rRNA) gene was performed by using set of primers suggested by Perez-miranda $e t$ al., (2007) and Mavrodi et al., (2001) (27 F5'AGAGTTTGATCCTGGCTCAG 3' and 1492 R- 5' GGTTACCTTGTTACGACTT 3'.
16S rDNA amplification was performed in a thermal cycler (Eppendorf Master cycler, Germany) with a $25 \mu$ l reaction mixture containing $50 \mathrm{ng}$ of genomic DNA, $0.2 \mathrm{mM}$ of each dNTPs, $1 \mu \mathrm{M}$ of each primer (Lee et al., 2005), $2.5 \mathrm{mM}$ of $\mathrm{MgCl}_{2}$, and $1 \mathrm{U}$ of Taq DNA polymerase (Bangalore Genei, India) and the buffer supplied with the enzyme. The output sequences were subjected for BLAST (Basic Local Alignment Search Tool) analysis to identify the cultures and to find out the nearest match of the cultures (http://www.ncbi.nlm.nih.gov). A neighborjoining phylogenetic tree was constructed using phylogeny fr software (http://www.phylogeny.fr/).

\section{Results and Discussion}

\section{Isolation and screening}

In all, total 14 isolates were obtained from root nodules of Mung bean and upon screening for nitrogen fixation, 7 were able to grow and flourish on nitrogen-free medium. There was no bacterial growth observed on $\mathrm{R}_{2} \mathrm{~A}$ medium plates on which the water from final rinse after surface sterilization was spreaded suggesting that nodule was completely surface sterilized.

\section{Detection of nif $\mathrm{H}$ gene}

Among 7 isolates which grew and flourished on nitrogen free medium, gave a single band of size $\sim 380$ bp (Fig. 1) indicating capacity to fix atmospheric nitrogen. Among all one was selected on the basis of its colony characteristics and growth potential on nitrogen free medium for plant growth promoting traits and characterized.

\section{Plant growth promoting traits}

Qualitative estimation of nitrogen fixation by nif $\mathrm{H}$ positive isolate found to fix $19.55 \mathrm{mg} \mathrm{N}$ 
$\mathrm{g}^{-1}$ of glucose consumed with IAA producing capability of $87.04 \mu \mathrm{g} \mathrm{ml}{ }^{-1}$ and ACC deaminase activity. However phosphate solubilization and siderophore production ability was absent.

\section{Characterization and identification}

Isolate AM2 was found to be gram negative, rod shaped, yellow pigments on DF and nutrient agar media, chemo-organotrophic (ortho-Nitrophenyl -P-galactoside positive, nitrate reducing, Ornithine utilizing, Phenyl alanine deaminating) and oxidase positive (Table 1). PCR amplification of 16S rRNA gene using universal primers (27 $\mathrm{F}$ and 1492 R) gave a single band of $1500 \mathrm{bp}$ on $2 \%$ agarose gel. From 16S $r$ RNA gene sequence isolate AM2 was identified as Chryseobacterium indologenes showing 97\% identity with $C$. indologenes strain LMG8337 and 95\% identity with Chryseobacterium indologenes strain NBRC 14944 which confirmed the isolate AM2 belongs to Chryseobacterium genus. The sequence analysis of partial 16S $r$ RNA gene was deposited in NCBI, GeneBank under accession number KF758545. The neighbourjoining phylogenetic tree of all isolates and related taxa were grouped together in figure 2 .

Table.1 Biochemical characters of Chryseobacterium indologenes AM2

\begin{tabular}{|l|c|}
\hline $\begin{array}{l}\text { ortho-Nitrophenyl -P- } \\
\text { galactoside }\end{array}$ & + \\
\hline Lysine utilization & - \\
\hline Ornithine utilization & + \\
\hline Urease & - \\
\hline Phenyl alanine deamination & + \\
\hline Nitrate reductase & + \\
\hline H2S production & - \\
\hline Citrate utilization & - \\
\hline Voges proskauer's & - \\
\hline Methyl red & - \\
\hline Indole & - \\
\hline Malonate utilization & - \\
\hline Esculine hydrolysis & + \\
\hline Arabinose & - \\
\hline Xylose & - \\
\hline Adonitol & - \\
\hline Rhamnose & - \\
\hline Cellobiose & - \\
\hline Melibiose & - \\
\hline Sachharose & - \\
\hline Raffinose & - \\
\hline Trehalose & - \\
\hline Glucose & + \\
\hline Lactose & - \\
\hline Oxidase & + \\
\hline
\end{tabular}


Fig.1 NifH gene amplification; M- 100 bp DNA ladder, 1- Std. Rhizobium sp. (Accn. KC787583), 2- E. cloacae AS1, 3- Isolate S5, 4- Isolate M3, 5- Isolate C. indologenes AM2, 6-

Isolate M5, 7- Isolate CP1, 8- Isolate CP5, 9- E. cloacae ACP3, 10- Isolate G2, 11- K. pneumoniae AG4, 12- P. aeruginosa ABG5, 13- E. ludwigiiABG6, 14- K. variicola ABG7

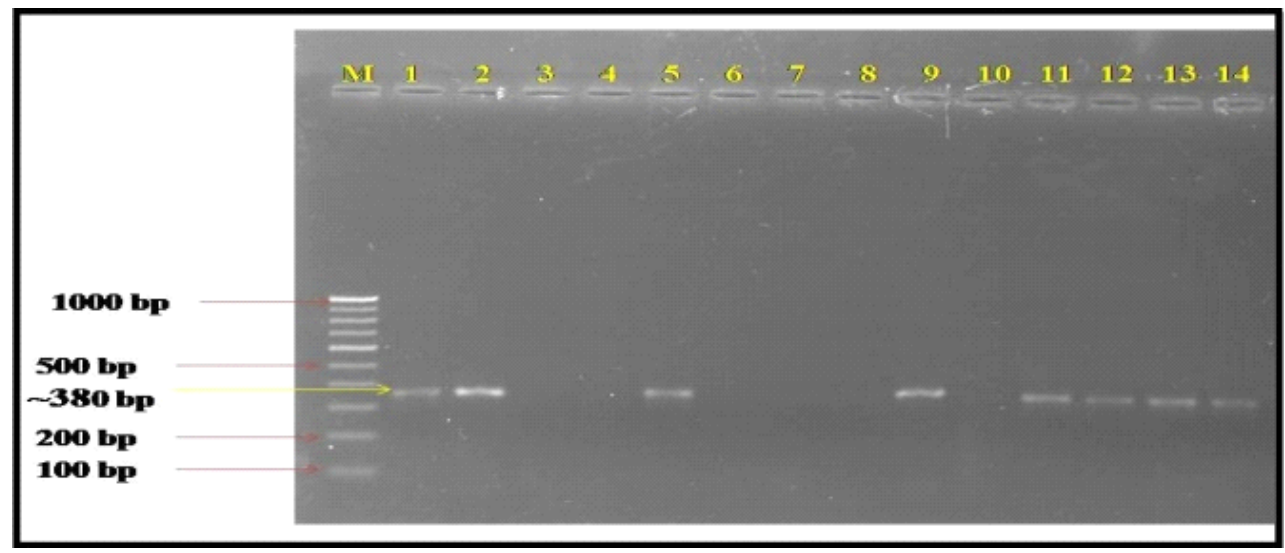

Fig.2 Neighbour-joining tree derived from 16S rRNA gene sequences showing the relationships between Chryseobacterium indologenes strain AM2 and related taxa

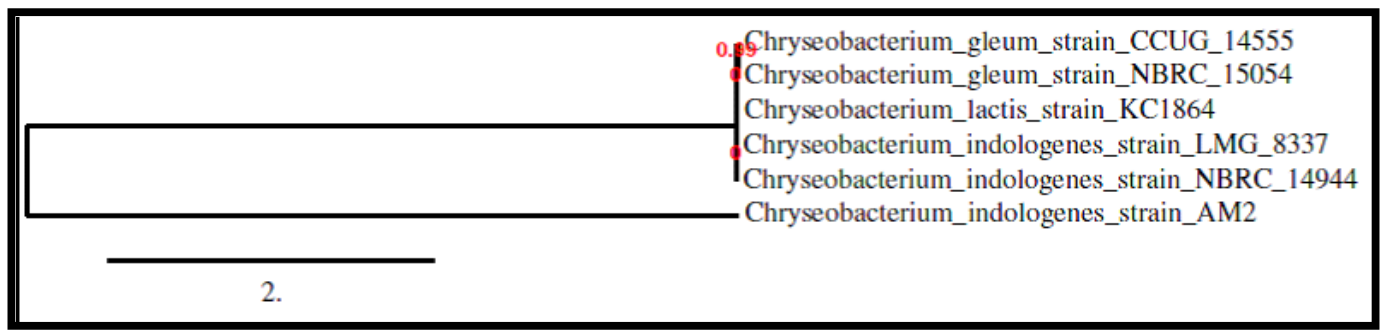

The co-existance of non-rhizobial bacteria like $K$. pneumoniae, $P$. fluorescence, Bacillus sp. and Penibacillus sp. were found inside the root nodules (Zhang et al., 1996; Rajendran et al., 2008; Ibanez et al., 2009; Egamberdieva et al., 2010; Tariq et al., 2012; and Pandya et al., 2013), even though there is high specificity between legumes and Rhizobium. In present study, $C$. indologenes AM2 a potential plant growth promoting nonrhizobial strain was isolated from Vigna radiata root nodule. It is a yellow pigmented, Gram-negative, rod shaped, chemoorganotrophic (nitrate reductase) and oxidase positive; can be found in soil, plants, foodstuffs and water sources. Different researchers suggest that, besides rhizobia; non-rhizobia are also present inside root nodules which may have beneficial effects on the host plant (Vessey 2003; Kuklinsky et al., 2004; Ibanez et al., 2009; Tariq et al., 2012). $C$. indologenes possess nifH gene and plant growth promoting traits like nitrogen fixation and production of enzyme ACC deaminase. Moreover, it is also capable of producing IAA which plays a crucial role in plant growth and development by inducing the cell differentiation and regeneration of the vascular tissues (Dalal and Kulkarni, 2013).

Earlier Chryseobacterium sp. were isolated from different niche like contaminated sites (Marques et al., 2001; Zhou et al., 2007), water samples (Kumar et al., 2011), soil (Tai 
et al., 2006), rhizosphere (Cho et al., 2010). However Mung bean nodule contains $90 \%$ strains of Bradyrhizobium japonicum, Bradyrhizobium liaoningense, Bradyrhizobium yuanmingense and Bradyrhizobium elkanii, while the rest belong to Sinorhizobium and Rhizobium (Zhang et $a l ., 2008)$. Only few studies reported presence of non rhizobial bacteria in root nodules of mungbean (Tariq et al., 2012; Pandya et al., 2013). In present study, to the best of our knowledge and literature surveyed endophytic non rhizobial $C$. indologenes AM2 isolated first time from root nodules of mungbean possessing plant growth promoting traits like nitrogen fixation, IAA production and ACC deaminase activity.

\section{References}

Andrews, M., Hodge, S., Raven, J. 2010. Positive plant microbial interactions. Annals of Appl. Biol., 317-320.

A.O.A.C. 1965. Official methods of analysis of the association of official agricultural chemists. $10^{\text {th }}$ Ed pp-744-745.

Balachandar, D., Raja, P., Kumar, K. and Sundaram, S.P. 2007. Non-rhizobial nodulation in legumes. Biotechechnol. Mol. Biol. Rev., 2(2): 049-057.

Cho, S.H., Lee, K.S., Shin, D.S., Han, J.H., Park, K.S., Lee, C.H., Park, K.H., et al. 2010. Four new species of Chryseobacterium from the rhizosphere of coastal sand dune plants, C. elymi sp. nov., $C$. hagamense sp. nov., $C$. lathyri sp. nov. and $C$. rhizosphaerae sp. nov. Systemic and Appl. Microbiol., 33(3): 122-7.

Dalal, J. and Kulkarni, N. 2013. Antagonistic and plant growth promoting potentials of indigenous endophytic bacteria of Soybean (Glycine $\max$ L. Merril). Curr. Res. Microbiol. Biotechnol., 1(2): 62-69.

Duan, J., Müller, K.M., Charles, T.C., Vesely,
S., Glick, B.R. 2009. 1aminocyclopropane-1-carboxylate (ACC) deaminase genes in rhizobia from southern Saskatchewan. Microbial Ecol., 57(3): 423-36.

Egamberdieva, D., Berg, G., Lindstrom, K., Rasanen, L.A. 2010. Co-inoculation of Pseudomonas spp. with Rhizobium improves growth and symbiotic performance of fodder galega (Galega orientalis Lam.). European J. Soil Biol., 46: 269-272.

Glickmann, E. and Dessaux, Y. 1995. A critical examination of the specificity of the salkowski reagent for indolic compounds produced by phytopathogenic bacteria. Appl. Environ. Microbiol., 61(2): 793.

Holt, J.G., Krieg, N.R., Peter, P.H.A., Staley, J.T. and Williams, S.T. 1994. Bergeys Manual of Determinative Bacteriology $9^{\text {th }}$ Edition. Pub: William and Wilkins, Baltimore, Maryland pp: 559.

http://www.ncbi.nlm.nih.gov

http://www.phylogeny.fr/

Ibanez, F., Angelini, J., Taurian, T., Tonelli, M.L., Fabra, A. 2009. Endophytic occupation of peanut root nodules by opportunistic Gammaproteobacteria. Systemic and Appl. Microbiol., 32: 4955.

Jhala, Y.K., Vyas, R.V., Shelat, H.N., Patel, H.K., Patel, H.K., Patel, K.T. 2014. Isolation and characterization of methane utilizing bacteria from wetland paddy ecosystem. World J. Microbiol. Biotechnol., 30(6): 1845-60.

Kuklinsky, S.J., Araujo, W.L., Mendes, R., Geraldi, I.O., Pizzirani-Kleiner, A.A. and Azevedo, J.L. 2004. Isolation and characterization of soybean-associated bacteria and their potential for plant growth promotion. Environ. Microbiol., 6: 1244-1251.

Kumar, P.A., Srinivas, T.N.R., Prasad, R. and Shivaji, S. 2011. Identification of fruity 
aroma-producing compounds from Chryseobacterium sp. isolated from the Western Ghats, India. Curr. Microbiol., 63(2): 193-7.

Lee, K.D., Bai, Y., Smith, D., Han, H.S. and Supanjani. 2005. Isolation of plantgrowth promoting endophytic bacteria from Bean nodules. Res. J. Agri. Biol. Sci., 1(3): 232-236.

Li, J.H., Wang, E.T., Chen, W.F. and Chen, W.X. 2008. Genetic diversity and potential for promotion of plant growth detected in nodule endophytic bacteria of soybean grown in Heilongjiang province of China. Soil Biol. Biochem., 40: 238-246.

Lin, D.X., Wang, E.T., Tang, H., Han, T.X., He, Y.R., Guan, S.H. and Chen, W.X. 2008. Shinella kummerowiae sp. nov., a symbiotic bacterium isolated from root nodules of the herbal legume Kummerowia stipulacea. Int. J. Systematic and Evol. Microbiol., 58: 1409-1413.

Marques, A.P.G.C., Pires, C., Moreira, H., Rangel, A.O.S.S. and Castro, P.M.L. 2001. Assessment of the plant growth promotion abilities of six bacterial isolates using Zea mays as indicator plant. Soil Biol. Biochem., 42(8): 12291235.

Mavrodi, O.V., McSpadden, G.B.B., Mavrodi, D.V., Bonsall, R.F., Weller, D.M. and Thomashow, L.S. 2001. Genetic diversity of phlD from 2, 4diacetylphloroglucinol-producing fluorescent Pseudomonas sp. Phytopathol., 91: 35-43.

Mirhendi, H., Diba, K., Rezaei, A., Jalalizand, N., Hosseinpur, L. and Khodadadi, H. 2007. Colony-PCR Is a Rapid and Sensitive Method for DNA Amplification in Yeasts. Iranian $J$. Public Health, 36(1): 40-44.

Moulin, L., Munive, A., Dreyfu, B. and Boivin-Masson, C. 2000. Nodulation of legumes by members of the betasubclass of Proteobacteria. Nature, 411: 948-950.

Pandya, M., Kumar, G.N. and Rajkumar, S. 2013. Invasion of rhizobial infection thread by non-rhizobia for colonization of Vigna radiata root nodules. FEMS Microbiol. Lett., 1-8.

Pongsilp, N. and Nuntagij, A. 2007.Selection and characterization of mungbean root nodule bacteria based on their growth and symbiotic ability in alkaline conditions. Suranaree J. Sci. Technol., 14(3): 277-286.

Rajendran, G., Patel, M.H. and Joshi, S.J. 2008. Isolation and characterization of nodule associated Exiguobacterium sp. from the root nodules of Fenugreek (Trigonella foenum-graecum) and their possible role in plant growth promotion. Int. J. Microbiol., 1-8.

Rivas, R., Vela'zquez, E., Valverde, A., Mateos, P. F. and Martı'nez-Molina, E. 2001. A two primers random amplified polymorphic DNA procedure to obtain polymerase chain reaction fingerprints of bacterial species. Electrophoresis, 22: 1086-1089.

Rubio, L.M. and Ludden, P.W. 2002. The gene products of the nif regulon. In: Leigh GJ editor, Nitrogen fixation at the millennium. Elsevier Sci., 101-136.

Schwyn, B. and Neilands, J.B. 1987. Universal chemical assey for detection and determination of siderophores. Annals of Biochem., 160: 47-56.

Selvakumar, G., Kundu, S., Gupta, A.D., Shouche, Y.S. and Gupta, H.S. 2008. Isolation and characterization of nonrhizobial plant growth promoting bacteria from nodules of Kudzu (Pueraria thunbergiana) and their effect on wheat seedling growth. Curr. Microbiol., 56: 134-139.

Sy, A., Giraud, E., Jourand, P., Garcia, N., Willems, A., de Lajudie, P., Prin, Y., 
Neyra, M., Gillis, M. et al. 2001. Methylotrophic Methylobacterium bacteria nodulate and fix nitrogen in symbiosis with legumes. J. Bacteriol., 183: 214-220.

Tai, C.J., Kuo, H.P., Lee, F.L., Chen, H.K., Yokota, A., and Lo, C.C. 2006. C. taiwanense sp. nov., isolated from soil in Taiwan. Int. J. Systematic and Evol. Microbiol., 56(8): 1771-6.

Tariq, M., Hameed, S., Yasmeen, T. and Ali, A. 2012. Non-rhizobial bacteria for improved nodulation and grain yield of mung bean [Vigna radiata (L.) Wilczek]. African J. Biotechnol, 11(84): 15012- 15019.

Taurian, T., María, S.A., Jorge, G.A., María, L.T., Liliana, L., Dayana, P., Fernando, I. and Adriana, F. 2010. Phosphatesolubilizing peanut associated bacteria: screening for plant growth-promoting activities Tania. Plant Soil, 329: 421431.

Vandamme, P., Goris, J., Chen, W.M., de Vos, P. and Willem, A. 2002. Burkholderia tuberum sp. nov. and Burkholderia phymatum sp. nov. nodulate the roots of tropical legumes. Systemic and Appl. Microbiol., 25: 507512.

Vessey, J.K. 2003. Plant growth promoting rhizobacteria as biofertilizers. Plant and Soil, 255: 571-586.

Zhang, F., Dashti, N., Hynes, R.K., Smith, D.L. 1996. Plant growth promoting rhizobacteria and soybean [Glycine max (L) Merr] nodulation and nitrogen fixation at suboptimal root zone temperatures. Annals of Bot., 77: 453459.

Zhou, Y., Dong, J., Wang, X., Huang, X., Zhang, K.Y., Zhang, Y.Q., Guo, Y.F., et al. 2007. C. flavum sp. nov., isolated from polluted soil. Int. J. Systematic and Evol. Microbiol., 57(8): 1765-9.

Zurdo-Pineiro, J.L., Rivas, R., Trujillo, M.E., Vizcaino, N., Carrasco, J.A., Chamber, M., Palomares, A., Mateos, P.F., Martınez-Molina, E. and Velazquez, E. 2007. Ochrobactrum cytisi sp. nov., isolated from nodules of Cytisus scoparius in Spain. Int. J. Systematic and Evol. Microbiol., 57: 784-788.

\section{How to cite this article:}

Archana Dhole, Harsha Shelat and Deepak Panpatte. 2017. Chryseobacterium indologenes A Novel Root Nodule Endophyte in Vigna radiata. Int.J.Curr.Microbiol.App.Sci. 6(4): 836-844. doi: https://doi.org/10.20546/ijcmas.2017.604.104 